\title{
AN ANALYSIS OF WORKING CAPITAL EFFICIENCY OF COMPANIES LISTED ON SUSTAINABILITY INDEX BY INDEX METHOD ${ }^{1}$
}

\author{
DOI: 10.17261/Pressacademia.2020.1206 \\ JEFA- V.7-ISS.2-2020(3)-p.94-102
}

\section{Ilkut Elif Kandil Goker}

Kirikkale Univesity, Department of Business Administration, Kirikkale, Turkey. elifkandil@kku.edu.tr , ORCID: 0000-0002-5290-3514

Date Received: April 10, 2020

Date Accepted: May 15, 2020

To cite this document

Kandil Goker, I.E., (2020). An analysis of working capital efficiency of companies listed on sustainability index by index method. Journal of Economics, Finance and Accounting (JEFA), V.7(2), p.94-102

Permanent link to this document: http://doi.org/10.17261/Pressacademia.2020.1206

Copyright: Published by PressAcademia and limited licensed re-use rights only.

\begin{abstract}
Purpose - In the 21st century, social and environmental risks have been increasing in global economies day by day. Since companies focus on profit and value maximization primarily, they ignore care for main production factors i.e. labor and natural resources. However, in recent years, production, management, and financing policies, in which social and environmental issues are taken into consideration, have started to be developed in this context. Sustainable development has a policy feature that the effects of the investments will be seen in the long term. Therefore, efficient working capital management is important in these companies, as companies that start to act by adopting the sustainability approach will not be able to benefit from the added value created in the short term. In this context this study aims to reveal the working capital management efficiency performance of sustainable companies.

Methodology - his study aims to calculate the working capital management efficiency of 19 companies, which are listed on the BIST Sustainability Index (XUSRD), created in 2014, between 2015 and 2018, by using the Index method developed by Bhattacharya (1997). Besides, the Wilcoxon Signed Ranks Test is used to see whether there is a significant difference between the working capital efficiency values of the companies listed on the sustainability index before and after their inclusion.

Findings- The companies' working capital management index values decrease after being included in the sustainability index. Additionally, the difference between the working capital management index values before and after being included in the corporate governance index is found to be significant.

Conclusion- The findings show that companies aiming to contribute to the world in terms of sustainability with a long-term social and environmental dimension should focus more on short-term assets and liabilities management.
\end{abstract}

Keywords: BIST Sustainability Index, Working Capital Management, Index Method JEL Codes: G30, G32, M14

\section{INTRODUCTION}

The concept of sustainable development has been the subject of focus in the development of international policies with the Brundtland Report, which was first presented in the World Commission on Environment and Development in 1987. In this report, sustainable development is defined as meeting today's development requirements without risking the needs of future generations to meet their needs (Ameer \& Othman, 2012:61). Within the framework of the sustainability approach, the management process of the companies taking into consideration the needs of the society enables more efficient use of scarce resources, sales of products that do not harm the environment, increasing revenues and transparency, decreasing conflicts of interest and ultimately increasing the value of the company (Lo \& Sheu, 2007; Laskar, Chakraborty \& Maji, 2017). The profit-oriented management approach to maximize shareholder value, which is the main target of the traditional financial management approach, evolves and turns towards stakeholder benefit maximization, which considers a wider segment in

\footnotetext{
${ }^{1}$ An earlier version of this manuscript was presented at the International Conference on Current Developments on Science, Technology and Social Science, Ankara, Turkey, 2019.
} 
modern societies. It is thought that the adoption of a more sustainability-oriented approach by firm shareholders will prevent managers from fighting between long-term sustainable growth and short-term cost-effectiveness (Pérez, 2003). Besides, it is thought that if a company listed on any stock exchange index with a corporate responsibility understanding, that company can obtain alternative funds from unconventional investors who care about sustainable development (Ortas \& Moneva, 2011). According to legitimacy theory there is a belief that companies influence society. If the companies disclose their corporate social activities which are key pillars of sustainable development, they receive more appreciation from the members of the community (Mallouh \& Tahtamoni, 2018). In this sense, companies have started to act with the corporate sustainability understanding for the last 30 years. The first sustainability index DJSI was introduced in 1999 in the New York Stock Exchange. The companies listed on this index are regarded as they fulfill all criteria of sustainability development (Santis et. al., 2016). The positive effect of sustainability on the companies began to be the subject of empirical studies in the 2000 s. Many studies examine the effect of acting with a sustainability approach on the financial performance of companies. Some of these studies suggest that there is a positive relationship between sustainability and financial performance (Ngwakve, 2009; Guindry \& Patten, 2010; Schadewitz \& Niskala, 2010; Burhan \& Rahmanti, 2012), some are negative (Lopez, Garcia \& Rodriguez., 2007; Detre \& Gunderson, 2011;) while some suggest that there is no significant relationship between them (Ziegler, Rennings \& Schroder, 2007; Adams, Thornton \& Sepehri, 2012; Buys, Oberholzer \& Andrikopoulos, 2011; Venanzi, 2012;). However, how the companies' short-term debt payment powers, their liquidity, their ability to fulfill their short-term responsibilities to continue their core activities will be affected as a result of adopting the understanding of sustainability has not yet been subject to an academic study. This study aims to contribute to the literature in this sense.

The remainder of the study consists of two sections. In the second section, the literature on the impact of sustainability on the performances of the companies, in the third section, the data set, the definition of the variables, the method, and the findings are submitted. Consequently, concluding remarks are given in the last section.

\section{LITERATURE REVIEW}

The impact of sustainability on companies is a new topic for many developing countries. Although studies on the impact of sustainability on companies' financial performance have been mostly investigated in the last decade, no study which examines the impact of sustainability on working capital management has been found yet in the literature review.

Ameer and Othman (2012) aim to reveal whether companies that act with sustainability understanding perform a higher financial performance compared to other companies in their research conducted in 2008 in the best 100 sustainable global companies' samples from 300 companies operating in developed and developing countries. According to the findings of the panel data analysis which is conducted by using the 2006-2010 financial statement data, they find that companies acting with a sense of sustainability have a higher rate of growth and asset profitability, higher pre-tax profit, and cash flow from operations than companies in the control group. They also reveal that there is a two-way relationship between corporate social responsibility and financial performance, which is the main indicator of acting with a sense of sustainability through causality analysis. Fettahoğlu (2014), who uses different variables other than mostly used performance indicators such as asset profitability, equity profitability, Tobin $Q$, finds a negative relationship between leverage ratio and social responsibility components. Based on this finding, he states that the sponsorship of culture and art activities decrease since the borrowing level of firm and financial risk increase. Düzer and Önce (2017) compare 30 companies that published sustainability reports according to GRI reporting principles in the 2008-2014 period and 26 companies with a similar asset size in the same sector that did not publish sustainability reports. In the study, two independent sample t-tests and Mann Whitney $U$ test examine whether the financial performance of companies that publish and do not publish sustainability reports differ. According to the findings, it is stated that the companies that publish sustainability reports have a lower price/earnings ratio, however, their return on assets and return on equity, which are selected as financial performance indicators, are higher in companies that publish sustainability reports. Önder (2018) also investigates whether being a sustainable firm has an impact on the profitability of the firm in Turkey. Using the data of 33 companies that have GRI sustainability reports and listed on BIST in 2015, they applied multiple regression methods. According to the findings, it is concluded that the sustainability of companies has a statistically significant but low impact on profitability. Also, it is observed that the environmental score, which is one of the sub-titles of sustainability, has a significant impact on profitability. Yıldırım, Kocamış \& Tokur (2018) aim to reveal whether there is a significant change in the activities and financial performances of the companies listed on the BIST Sustainability Index compared to the periods before they are listed on the index. For this purpose, by comparing the data of the five quarters before the companies listed on the sustainability index and the two quarters after being listed on the sustainability index, it was determined whether there is a significant difference between the periods. As a result of the research, it is stated that there are significant differences in asset turnover, financial leverage, and equity profitability performance indicators before and after the index coverage. Unlike previous studies, Gürünlü (2019) aims to demonstrate the long-term effect of companies' spending on their financial success to be included in the sustainability index using panel data estimation methods. According to his findings, there is a weak relationship between high performance in sustainability and financial success. He states that 
this weak relationship stems from the inability of investors to understand the efforts made for sustainability. As can be seen in the literature review, the findings on how the profitability of sustainable companies are affected conclude that profitability is positively affected by sustainability.

As far as the author knows although there is no empirical study on the question of how to act with the understanding of sustainability have an impact on companies' working capital management, a few studies are dealing with the impact on the liquidity. Among these studies, Santis et. al. (2016) compares the profitability and liquidity ratios of companies listed on the sustainability index and companies in the Sao Paulo Stock Exchange Index. According to the findings, they state that there is no significant difference between the two groups in terms of profitability and liquidity. Whether being a sustainable firm or not is not a determining factor; instead, they state that other characteristics such as sectorial classification are more deterministic. Subramaniam and Samuel (2015) on the other hand, aim to explore the relationship between the level of disclosure of corporate social responsibility and liquidity of Malaysian companies. 194 Malaysian companies, listed on Malaysia Stock Exchange in 2009 constitute the sample of their study. They find positive and very strong relationship between the level of disclosure of corporate social responsibility and liquidity of companies.

\section{DATA AND METHODOLOGY}

\subsection{Sample and Data}

The working capital management effectiveness levels of the companies listed on the BIST Sustainability index before and after being listed on the index are calculated in this study. Thus, it is aimed to reveal the effect of inclusion in the index on working capital management. Since the outputs of sustainability-oriented activities will be seen in the long term, the importance of working capital management for sustainable companies increases. Owing to the activities carried out for sustainability are related to working capital, there is an increasing need for working capital for companies after they are included in the index. Sustainability index, created with the code XUSRD on November 4, 2014, included 15 companies in the first year. In the following years, this number increased every year and reached a total of 50 companies as of 2018 . Some companies in the XUSRD index are excluded from the index if they fail to meet the minimum requirements. For this reason, companies within the scope of the index are updated every year. In this study, the companies included in the index every year since 2015 are included in the sample to create a homogeneous sample group. Since 2014 is the year when the index was created, it is excluded from the period of observation. The four years before 2014 (2010-2013 period) and the next four years (2015-2018 period) constitute the period of the study. 19 companies listed on the index without interruption from 2015 through 2018 constitute the sample of the study. Information about the companies is as shown in Table 1. Financial statements of the companies are obtained from the FINNET database; consists of balance sheet and income statement items. As an alternative to the rate analysis and regression model used in the literature to examine the effectiveness of companies in working capital management, this study uses the Index method, in which the working capital effectiveness index is measured. This method is developed by Bhattacharya (1997).

Table 1: Companies in the Sample of the Research

\begin{tabular}{llll}
\hline 1. & Aksa Enerji & 11. & Petkim \\
\hline 2. & Anadolu Efes & 12. & TAV \\
\hline 3. & Arçelik & 13. & Tofaş \\
\hline 4. & Aselsan & 14. & Turkcell \\
\hline 5. & Brisa & 15. & Tüpraş \\
\hline 6. & Doğuş Otomotiv & 16. & Türk Hava Yolları \\
\hline 7. & Ereğli Demir Çelik & 17. & Türk Telekom \\
\hline 8. & Ford Oto & 18. & Ülker \\
\hline 9. & Migros & 19. & Vestel \\
\hline 10. & Otokar & & \\
\hline
\end{tabular}

Total current assets and sales revenues of companies have an important role in working capital management. The increase in total current assets and sales have a direct increase in working capital. This study aims to measure the effectiveness of working capital management. Therefore, the changes in current assets and sales are analyzed graphically before and after being listed on the sustainability index. The average values of the working capital of companies are as shown in Figure 1 . For all companies, there is an increase in the average working capital compared to the period before being included in the sustainability index. 
Figure 1: The Trends of Average Total Working Capital

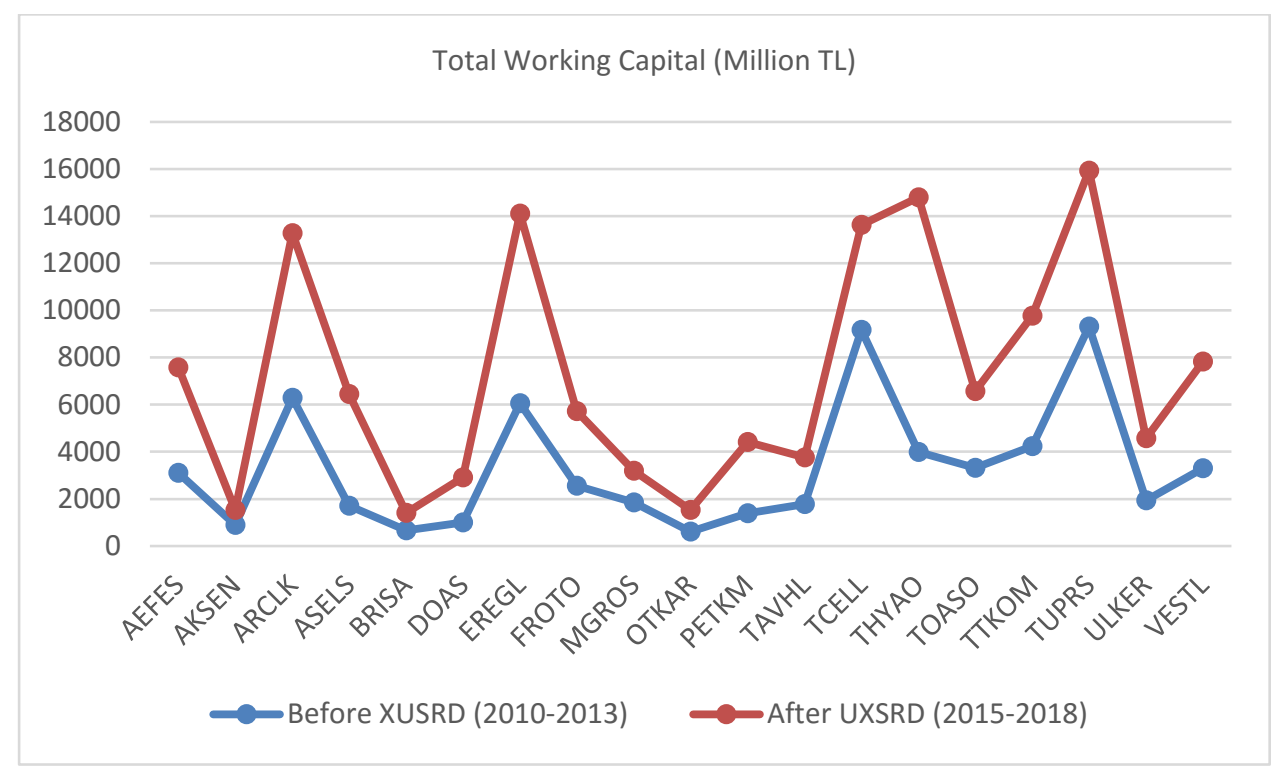

Average values of sales revenues of companies are as shown in Figure 2. As can be seen from this figure, sales similar to current assets do not decrease in any firm. However, only the increase in the current assets and sales of the companies does not show that these companies carry out effective working capital management. Therefore, in this study, the Index model is used to determine the effectiveness of working capital management.

Figure 2: The Trends of Average Sales Revenue

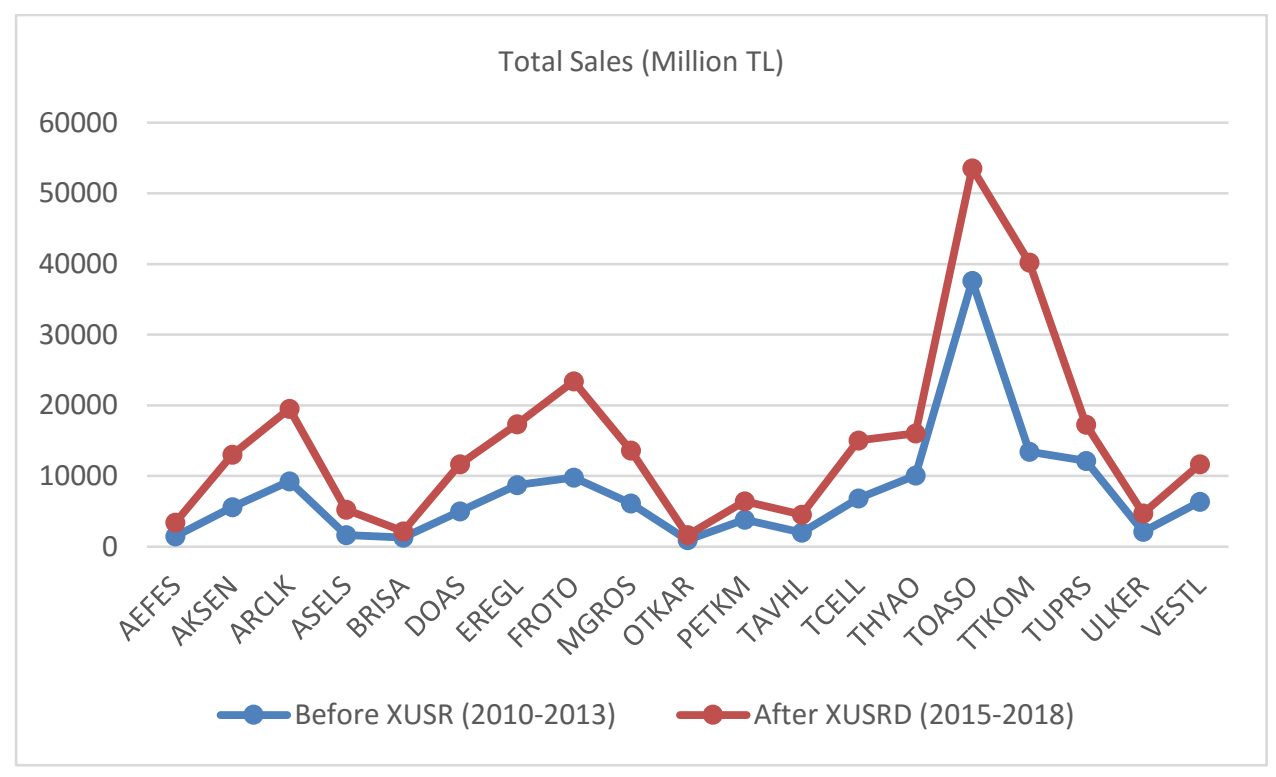

\subsection{Methodology}

According to Bhattacharya (1997), the effectiveness of a firm depends on four factors. These factors are increasing sales, keeping the costs under control, keeping the amount of working capital proportional to the sales and increasing profit. In this sense, the greatest importance is given to sales performance. The sales performance of the firm can be measured through the index obtained by proportioning current year sales revenues to previous year sales revenues (St/St-1). Bhattacharya 
(1997) defines the first step in measuring the company's effectiveness in working capital management as the calculation of the performance index (PI). The performance index is obtained by multiplying the sales index with the working capital index. The working capital index of the companies is calculated by proportioning the current year amount in each item of current assets, which is expressed as gross working capital, to the previous year amount and by weighing the sum of these ratios by dividing the number of components. In the second stage, the utilization index (UI) is calculated by dividing the previous year's current asset/sales to the current year's current assets/ sales. The utilization index measures companies' ability to leverage their current assets in order to generate sales revenue. At the last stage, the working capital efficiency index is calculated by multiplying the companies' performance index value and the utilization index value. The fact that this index value is greater than 1 indicates that the company is effective in working capital management.

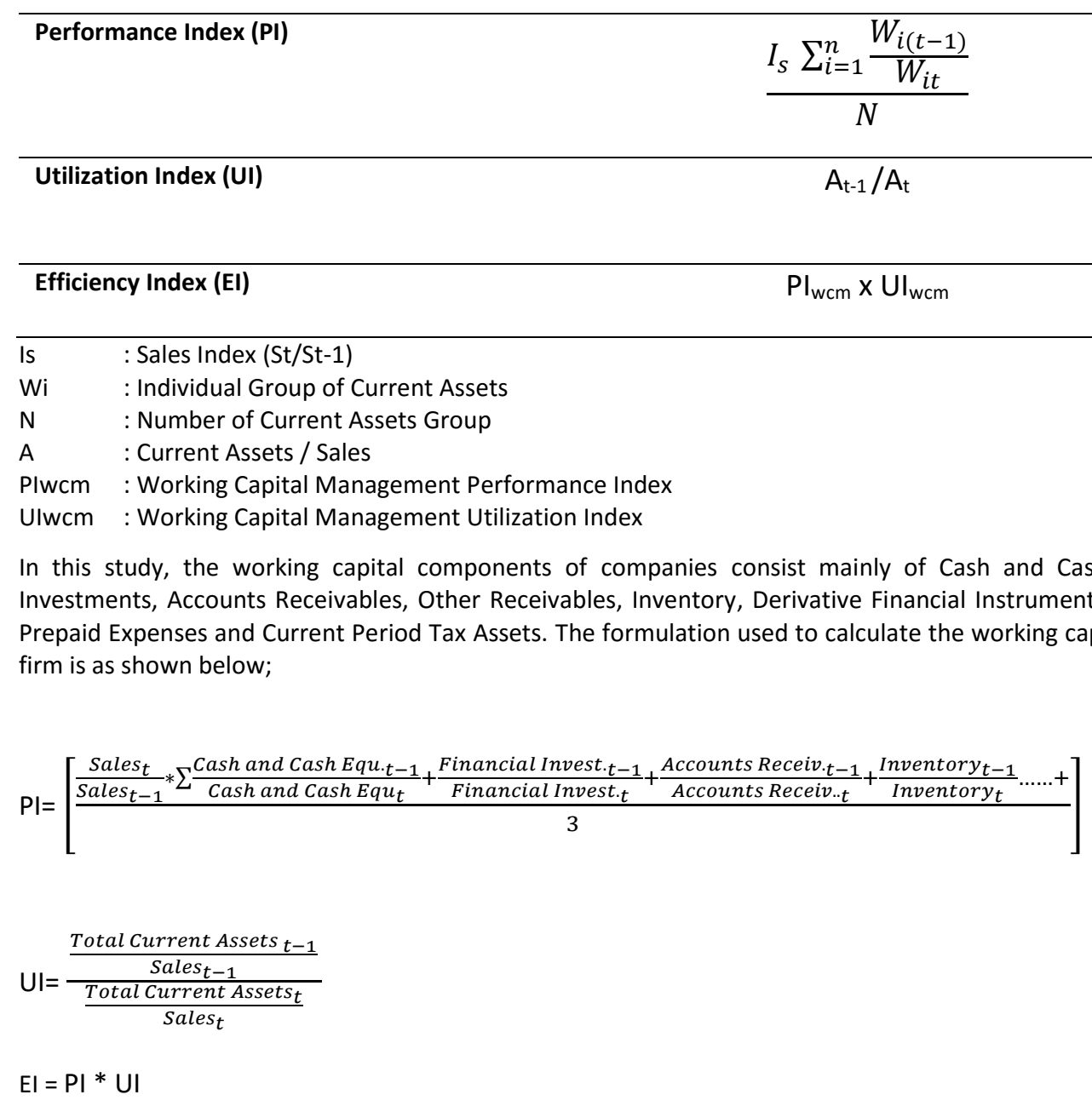

\subsection{Results and Discussion}

The findings are summarized in Tables 2, 3, and 4. Table 2 shows the working capital performance indices of the companies listed in the sustainability index during the period of observation. The fact that the PI value is greater than 1 indicates that the proportional increase in the sales of the firm is higher than the average of the proportional increase in each working capital element, therefore the working capital is managed effectively. Considering the index values on a yearly basis, the number of companies with a performance index above 1 before 2014 is 11, 12, 14, and 9 in 2010, 2011, 2012, and 2013, respectively. After 2014, these numbers are $9,8,13$, and 11 , respectively. Three years after entering the sustainability index, the number of companies with a performance index above 1 decreased. Average performance indices of companies are compared before and after the year when the sustainability index is created. In this comparison, it is observed that a decrease in the average PI value of 13 companies among 19 companies in total. The highest decrease is seen in Otokar and Tofaş. 
Table 2: Performance Indices (PI) of Companies from 2010 to 2018

\begin{tabular}{|c|c|c|c|c|c|c|c|c|c|c|c|}
\hline PI & 2010 & 2011 & 2012 & 2013 & Mean & 2014 & 2015 & 2016 & 2017 & 2018 & Mean \\
\hline AKSEN & 1.02 & 0.84 & 1.37 & 5.39 & 2.15 & \multirow{20}{*}{ 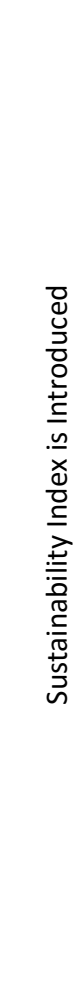 } & 12.13 & 0.94 & 1.39 & 1.82 & 4.07 \\
\hline AEFES & 0.76 & 1.03 & 1.62 & 0.93 & 1.08 & & 4.29 & 0.69 & 2.18 & 1.80 & 2.24 \\
\hline ARCLK & 1.52 & 0.68 & 0.93 & 0.68 & 0.95 & & 0.99 & 1.23 & 1.02 & 0.82 & 1.02 \\
\hline ASELS & 1.66 & 1.31 & 0.58 & 1.64 & 1.30 & & 0.82 & 0.88 & 1.19 & 0.91 & 0.95 \\
\hline BRISA & 0.84 & 1.92 & 30.90 & 0.79 & 8.61 & & 0.96 & 0.99 & 5.23 & 0.87 & 2.01 \\
\hline DOAS & 1.93 & 1.18 & 1.29 & 1.02 & 1.36 & & 0.60 & 0.72 & 1.31 & 0.64 & 0.82 \\
\hline EREGL & 0.65 & 28.86 & 0.80 & 0.86 & 7.79 & & 1.06 & 0.87 & 5.38 & 0.74 & 2.01 \\
\hline FROTO & 0.89 & 1.08 & 1.05 & 3.99 & 1.75 & & 1.14 & 0.72 & 0.85 & 1.09 & 0.95 \\
\hline MGROS & 0.74 & 6.19 & 2.28 & 0.96 & 2.54 & & 1.07 & 1.56 & 0.52 & 0.81 & 0.99 \\
\hline OTKAR & 35.20 & 7.94 & 1.56 & 2.45 & 11.79 & & 2.22 & 1.07 & 0.83 & 4.47 & 2.15 \\
\hline PETKM & 1.00 & 1.32 & 1.48 & 0.89 & 1.17 & & 0.88 & 1.95 & 1.06 & 25.82 & 7.43 \\
\hline TAVHL & 3.32 & 0.72 & 3.90 & 0.72 & 2.17 & & 1.58 & 1.25 & 0.98 & 1.38 & 1.30 \\
\hline TOASO & 3.44 & 1.01 & 41.60 & 0.79 & 11.71 & & 0.96 & 0.86 & 2.41 & 0.89 & 1.28 \\
\hline TCELL & 1.71 & 0.64 & 9.45 & 0.84 & 3.16 & & 0.89 & 1.81 & 0.98 & 1.88 & 1.39 \\
\hline TUPRS & 0.82 & 1.68 & 0.83 & 19.78 & 5.78 & & 1.03 & 0.73 & 1.05 & 2.10 & 1.23 \\
\hline THYAO & 1.36 & 1.09 & 1.07 & 2.54 & 1.52 & & 0.97 & 0.71 & 1.37 & 1.19 & 1.06 \\
\hline TTKOM & 0.82 & 0.88 & 0.90 & 0.92 & 0.88 & & 0.57 & 0.93 & 1.58 & 1.13 & 1.05 \\
\hline ULKER & 0.91 & 0.98 & 1.55 & 2.43 & 1.47 & & 0.88 & 5.41 & 0.89 & 0.95 & 2.03 \\
\hline VESTL & 1.10 & 0.68 & 10.97 & 1.17 & 3.48 & & 1.10 & 1.44 & 2.65 & 1.06 & 1.56 \\
\hline Year Based & 11 & 12 & 14 & 9 & & & 9 & 8 & 13 & 11 & \\
\hline
\end{tabular}

Table 3 shows the companies' utilization index values. If total current assets increase higher than the increase in sales, the degree of utilization of current assets will increase compared to sales. Thus, by increasing the utilization degree, it will be possible to shorten the duration of the companies' activity cycle. So it is desirable that the UI gets a value greater than 1 (Kaur ve Singh, 2013:348). When the index values are analyzed on a yearly basis, the number of companies with a utilization index of more than 1 before 2014 is 8,12,11, and 12 in 2010, 2011, 2012, and 2013, respectively. After 2014, these numbers are 5, 6,10 , and 8 , respectively. The number of companies with a utilization index of over 1 year decreased after entering the sustainability index. In this comparison, it was observed that a decrease in the average UI value of 13 companies among 19 companies in total.

Table 3: Utilization Indices (PI) of Companies from 2010 to 2018

\begin{tabular}{|c|c|c|c|c|c|c|c|c|c|c|c|}
\hline UI & 2010 & 2011 & 2012 & 2013 & Mean & 2014 & 2015 & 2016 & 2017 & 2018 & Mean \\
\hline AKSEN & 0.82 & 1.43 & 1.19 & 2.12 & 1.39 & \multirow{10}{*}{ 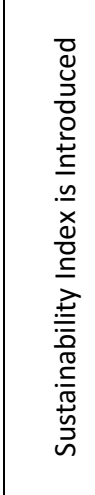 } & 0.85 & 0.69 & 1.13 & 0.79 & 0.87 \\
\hline AEFES & 1.05 & 1.05 & 0.71 & 1.27 & 1.02 & & 0.93 & 0.84 & 0.81 & 1.30 & 0.97 \\
\hline ARCLK & 0.92 & 0.96 & 1.12 & 0.92 & 0.98 & & 1.02 & 0.97 & 1.05 & 0.91 & 0.99 \\
\hline ASELS & 1.52 & 1.31 & 0.78 & 1.26 & 1.21 & & 0.84 & 0.83 & 1.20 & 0.87 & 0.93 \\
\hline BRISA & 0.88 & 0.91 & 0.96 & 0.90 & 0.91 & & 0.80 & 0.91 & 1.24 & 1.11 & 1.01 \\
\hline DOAS & 1.18 & 1.00 & 1.05 & 1.02 & 1.06 & & 0.82 & 0.87 & 1.09 & 0.92 & 0.92 \\
\hline EREGL & 0.74 & 1.41 & 1.10 & 1.00 & 1.06 & & 0.96 & 0.71 & 1.20 & 0.95 & 0.95 \\
\hline FROTO & 0.96 & 0.99 & 1.18 & 1.17 & 1.07 & & 1.03 & 0.94 & 0.95 & 1.21 & 1.03 \\
\hline MGROS & 1.00 & 1.09 & 1.06 & 1.06 & 1.05 & & 0.98 & 0.97 & 0.91 & 1.03 & 0.97 \\
\hline OTKAR & 1.40 & 1.40 & 0.88 & 1.19 & 1.22 & & 0.65 & 0.95 & 0.97 & 0.85 & 0.85 \\
\hline
\end{tabular}




\begin{tabular}{|c|c|c|c|c|c|c|c|c|c|c|}
\hline PETKM & 1.09 & 1.11 & 1.03 & 0.81 & 1.01 & 0.70 & 1.04 & 1.03 & 0.67 & 0.86 \\
\hline TAVHL & 0.75 & 1.08 & 0.93 & 1.03 & 0.95 & 1.00 & 1.22 & 0.99 & 0.97 & 1.05 \\
\hline TOASO & 3.00 & 0.89 & 0.92 & 1.10 & 1.48 & 0.98 & 1.19 & 0.99 & 1.16 & 1.08 \\
\hline TCELL & 0.94 & 0.85 & 0.97 & 0.91 & 0.92 & 1.60 & 0.73 & 1.15 & 0.92 & 1.10 \\
\hline TUPRS & 0.80 & 1.60 & 1.03 & 0.91 & 1.08 & 0.74 & 0.60 & 1.04 & 1.59 & 1.00 \\
\hline THYAO & 0.96 & 1.21 & 1.31 & 1.08 & 1.14 & 0.85 & 0.74 & 1.25 & 0.91 & 0.94 \\
\hline TTKOM & 0.79 & 1.02 & 0.98 & 0.93 & 0.93 & 0.81 & 1.02 & 0.98 & 1.09 & 0.97 \\
\hline ULKER & 0.99 & 0.97 & 1.06 & 1.24 & 1.07 & 0.77 & 1.07 & 0.86 & 0.93 & 0.91 \\
\hline VESTL & 1.03 & 0.95 & 1.27 & 0.77 & 1.00 & 0.93 & 1.07 & 0.85 & 1.17 & 1.01 \\
\hline Year Based & 8 & 12 & 11 & 12 & & 5 & 6 & 10 & 8 & \\
\hline
\end{tabular}

Finally, considering the companies' working capital efficiency indices (Table 4), the number of companies whose working capital activity index is above 1 before 2014 is 10, 11, 15, and 10 in 2010, 2011, 2012, and 2013, respectively. After 2014, these numbers are 10, 9, 14, and 12, respectively. In the two years after being listed on the sustainability index, the number of companies whose working capital efficiency index is above 1 decrease and it increases in the next 2 years. When the average working capital effectiveness indices of companies compared to the year before the sustainability index is created and the subsequent average working capital effectiveness indices, it is seen that the activities of Aselsan and Migros fall below 1. It has been determined that the working capital efficiency index values of 14 companies decrease in total. Considering the number of years that are efficient before and after the creation of the sustainability index, it is seen that the number of years that 7 companies are efficient decreases, 5 companies do not change and 7 companies increase.

Table 4: Working Capital Management Efficiency Indices (EI) of Companies from 2010 to 2018

\begin{tabular}{|c|c|c|c|c|c|c|c|c|c|c|c|}
\hline $\mathrm{EI}$ & 2010 & 2011 & 2012 & 2013 & Mean & 2014 & 2015 & 2016 & 2017 & 2018 & Mean \\
\hline AKSEN & 0.84 & 1.19 & 1.63 & 11.44 & 3.77 & \multirow{19}{*}{ 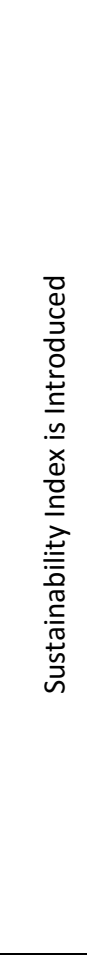 } & 10.29 & 0.65 & 1.58 & 1.43 & 3.49 \\
\hline AEFES & 0.80 & 1.08 & 1.15 & 1.18 & 1.05 & & 3.97 & 0.58 & 1.76 & 2.33 & 2.16 \\
\hline ARCLK & 1.40 & 0.65 & 1.04 & 0.63 & 0.93 & & 1.01 & 1.20 & 1.08 & 0.75 & 1.01 \\
\hline ASELS & 2.51 & 1.72 & 0.45 & 2.07 & 1.69 & & 0.68 & 0.73 & 1.43 & 0.79 & 0.91 \\
\hline BRISA & 0.75 & 1.75 & 29.78 & 0.71 & 8.24 & & 0.76 & 0.90 & 6.45 & 0.97 & 2.27 \\
\hline DOAS & 2.28 & 1.18 & 1.36 & 1.05 & 1.47 & & 0.49 & 0.63 & 1.42 & 0.59 & 0.78 \\
\hline EREGL & 0.48 & 40.74 & 0.88 & 0.86 & 10.74 & & 1.01 & 0.61 & 6.46 & 0.70 & 2.20 \\
\hline FROTO & 0.86 & 1.06 & 1.24 & 4.65 & 1.95 & & 1.18 & 0.68 & 0.81 & 1.32 & 1.00 \\
\hline MGROS & 0.74 & 6.74 & 2.40 & 1.02 & 2.73 & & 1.04 & 1.51 & 0.47 & 0.83 & 0.96 \\
\hline OTKAR & 49.29 & 11.10 & 1.37 & 2.91 & 16.17 & & 1.43 & 1.02 & 0.81 & 3.80 & 1.77 \\
\hline PETKM & 1.09 & 1.46 & 1.53 & 0.72 & 1.20 & & 0.62 & 2.03 & 1.09 & 17.19 & 5.23 \\
\hline TAVHL & 2.50 & 0.78 & 3.61 & 0.74 & 1.91 & & 1.58 & 1.53 & 0.98 & 1.34 & 1.36 \\
\hline TOASO & 10.32 & 0.90 & 38.08 & 0.87 & 12.54 & & 0.93 & 1.02 & 2.40 & 1.03 & 1.35 \\
\hline TCELL & 1.61 & 0.54 & 9.14 & 0.76 & 3.01 & & 1.42 & 1.31 & 1.12 & 1.73 & 1.40 \\
\hline TUPRS & 0.65 & 2.68 & 0.86 & 17.90 & 5.52 & & 0.77 & 0.44 & 1.09 & 3.34 & 1.41 \\
\hline THYAO & 1.30 & 1.32 & 1.39 & 2.75 & 1.69 & & 0.83 & 0.52 & 1.71 & 1.09 & 1.04 \\
\hline TTKOM & 0.65 & 0.90 & 0.88 & 0.86 & 0.82 & & 0.46 & 0.94 & 1.55 & 1.23 & 1.05 \\
\hline ULKER & 0.90 & 0.95 & 1.64 & 3.02 & 1.63 & & 0.68 & 5.77 & 0.77 & 0.89 & 2.03 \\
\hline VESTL & 1.12 & 0.65 & 13.91 & 0.91 & 4.15 & & 1.02 & 1.54 & 2.26 & 1.24 & 1.51 \\
\hline Year Based & 10 & 11 & 15 & 10 & & & 10 & 9 & 14 & 12 & \\
\hline
\end{tabular}


Since the 4-year average working capital efficiency index before being included in the sustainability index and the 4-year average working capital activity index after being included is mathematically different, the significance of this difference is also tested statistically. Firstly, the Shapiro-Wilk test is used to see whether the average working capital efficiency index series of 4 years before and after being included in the XUSRD index of 19 companies have normal distribution or not. The test results are as shown in Table 5.

Table 5: Normality Test Results

\begin{tabular}{ccc|ccc}
\hline \multicolumn{3}{c|}{ Kolmogorov-Smirnov } & \multicolumn{3}{c}{ Shapiro-Wilk } \\
\hline Statistic & $\mathrm{df}$ & Sig. & Statistic & df & Sig. \\
\hline, 248 & 19 &, 003 &, 752 & 19 &, 000 \\
\hline, 214 & 19 &, 022 &, 749 & 19 &, 000 \\
\hline
\end{tabular}

The $\mathrm{H}_{0}$ hypothesis of the Sapiro-Wilk test is "normal distribution". According to probability values, $\mathrm{H}_{0}$ hypothesis with $5 \%$ significance level cannot be accepted in the test results specified. It is determined that the series do not show normal distribution. If the series do not have normal distribution it is required to use a nonparametric test.

The Wilcoxon Signed Ranks test is used to examine whether the average working capital efficiency index series of 4 years before being included in the XUSRD and the average working capital efficiency index series of 4 years after being included in the XUSRD difference is significant. The findings are summarized in Table 6.

Table 6: Wilcoxon Test Result

\begin{tabular}{cc}
\hline & EO - ES \\
\hline$Z$ & $-2,575^{\mathrm{b}}$ \\
\hline Asymp. Sig. (2-tailed) &, 010 \\
\hline
\end{tabular}

This test is used as a non-parametric alternative of the t-test in paired samples. Since P-value is less than $0.05, H_{0}$ (There isn't a statistically significant difference) is not accepted and it is seen that there is a statistically significant difference between the series with $95 \%$ confidence.

\section{CONCLUSION}

This study investigates the change in working capital management effectiveness before and after being listed on the sustainability index and aims to determine whether the resulting mathematical difference is statistically significant. Using the Index method developed by Bhattacharya (1997), it is observed that the working capital efficiency of many companies decrease after being listed on the sustainability index. Considering the companies' working capital efficiency indices, the number of companies whose working capital activity index is above 1 before 2014 was 10, 11, 15, and 10 in 2010, 2011, 2012, and 2013, respectively. After 2014, these numbers are 10, 9, 14, and 12, respectively. In the two years after being listed on the sustainability index, the number of companies whose working capital efficiency index is above 1 decrease and it increases in the next 2 years. As stated in the methodology, effectiveness in the management of working capital depends on the performance and utilization of companies. When both performance and utilization indices are considered it is seen that especially the utilization indices of companies decrease. Thus it is concluded that after being listed in XUSRD, companies fail to leverage their current assets in order to generate sales revenue. The findings show that companies cannot manage their working capital well during the fulfillment of the obligations undertaken for sustainability understanding. Since the investments made for sustainability will show its benefits in the long term, the expenditures must be managed well in the short term.

\section{REFERENCES}

Adams, M., Thornton, B., \& Sepehri, M. (2012). The impact of the pursuit of sustainability on the financial performance of the firm. Journal of Sustainability and Green Business, 1, 1-14.

Ameer R. \& Othman R. (2012). Sustainability Practices and Corporate Financial Performance: A Study Based on the Top Global Corporations, Journal of Business Ethics, 108, 61-79.

Bhattacharya H. (2014). Working Capital Management Strategies and Techniques. PHI Learning Private Limited, Third Edition.

Burhan, A. H., \& Rahmanti, W. (2012).The Impact of Sustainability Reporting on Company Performance. Journal of Economics, Business, and Accountancy Ventura, 15(2), 257-272. 
Buys, P., Oberholzer, M., \& Andrikopoulos, P. (2011). An investigation of the economic performance of sustainability reporting companies versus non-reporting companies: A South African perspective. Journal of Social Sciences, 29(2), 151-158.

Detre, J. D., \& Gunderson, M. A. (2011). The Triple Bottom Line: What is the Impact on the Returns to Agribusiness?. International Food and Agribusiness Management Review, 14(4), 165-178.

Düzer M., Önce S. (2017). Kurumsal Sürdürülebilirlik Raporlaması ve Finansal Performans: BisT’te İşlem Gören Şirketler İçin Karşılaştırmalı Bir Analiz, Bilecik Şeyh Edebali Üniversitesi Sosyal Bilimler Enstitüsü Dergisi, 2(2), 637-648.

Fettahoğlu S. (2014). İşletmelerde Sosyal Sorumluluk ille Finansal Performans Arasındaki iliş̧ki: İmkb’ye Yönelik Bir Uygulama, Sosyal ve Beşeri Bilimler Dergisi, 6(1), 11-20.

Guidry, R. P., \& Patten, D. M. (2010). Market reactions to the first-time issuance of corporate sustainability reports: Evidence that quality matters. Sustainability Accounting, Management and Policy Journal, 1(1), 33-50.

Gürünlü M. (2019). Sürdürülebilirlik ve finansal performans arasındaki ilişki: BisT şirketleri üzerine bir araştırma, Muhasebe ve Finansman Dergisi (84), 177-190.

Kaur H. V., Singh S. (2013). Managing working capital efficiency in capital goods sector in India, Global Business Review, 14(2), $343-355$.

Laskar, N., Chakraborty T. K. \& Maji S. G. (2017). Corporate sustainability performance and financial performance: empirical evidence from Japan and India, Management and Labour Studies, 42(2), 88-106.

Lo, S., \& Sheu, H. (2007). Is corporate sustainability a value-increasing strategy for business? Journal Compilation, 15(2), 345-358.

Lopez, M. V., Garcia, A., \& Rodriguez, L. (2007). Sustainable development and corporate performance: A study based on the Dow Jones Sustainability Index. Journal of Business Ethics, 75(3), 285-300.

Mallouh A. A: \& Tahtamouni A. (2018). The impact of social responsibility disclosure on the liquidity of the Jordanian industrial corporation, International Journal of Managerial and Financial Accounting, 10(3), 273-300.

Ngwakwe, C. C. (2009). Environmental responsibility and firm performance: evidence from Nigeria. International Journal of Humanities and Social Sciences, 3(2), 97-103.

Ortas, E. Moneva J. M. (2014). Sustainability stock exchange indexes and investor expectations: Multivariate evidence from DJSI-Stoxx, Spanish Journal of Finance and Accounting, 40(151), 395- 416

Önder Ş. (2018). Impact of sustainability performance of company on its fınancial performance: an empirical study on Borsa Istanbul (BIST), Dumlupınar Üniversitesi Sosyal Bilimler Dergisi, 56 Nisan, 115-127.

Pérez R. (2003). About 'global responsibility' in management. Corporate Governance 3(3), 78-89.

Santis P., Albuquerque A., Lizarelli F. (2016). Do sustainable companies have a better financial performance? A study on Brazilian public companies, Journal of Cleaner Production, 133, 735-745.

Schadewitz, H., \& Niskala, M. (2010). Communication via responsibility reporting and its effect on firm value in Finland. Corporate Social Responsibility and Environmental Management, 17(2), 96-106.

Subramaniam, R. \& Samuel, S. (2015). Liquidity implication of corporate social responsibility disclosures: Malaysian capital market evidence, Journal of International Accounting Research, 15(1), 133-155.

Venanzi, D. (2012). Social Ratings and Financial Performance: An Instrumental Approach, SSRN 2188859.

Yıldırım G., Uzun Kocamış T. \& Tuncer Tokur E. (2018). Sürdürülebilirlik ve firma performansı: BiST sürdürülebilirlik endeksi şirketleri üzerine bir uygulama, Akademik Sosyal Bilimler Dergisi, 5(15), 90-96.

Ziegler, A., Rennings, K., \& Schroder, M. (2007). The effect of environmental and social performance on the shareholder value of European stock corporations, Environ Resources Econ, 37, 661-680. 